\title{
Sigurt Vitols* \\ Board Level Employee Representation and Tax Avoidance in Europe
}

https://doi.org/10.1515/ael-2019-0056

Published online April 27, 2021

Abstract: In part due to recent disclosures of large-scale tax evasion (e.g. Panama Papers), corporate tax avoidance has become a prominent public policy issue around the world. An increasing amount of research on this topic has focused on identifying the determinants of tax avoidance at the company and country level. Many newer studies examine differences in corporate governance as one of these determinants. However, this literature almost entirely neglects the role of board level employee representation (BLER), despite the fact that this form of 'stakeholder governance' is widespread in Europe. This paper addresses this gap in the literature by examining the relationship between BLER and tax avoidance at the company level. Two mechanisms are identified through which BLER might influence corporate tax behavior: 1) reduction in agency costs through monitoring and 2) the voting power of workers as board members to enter into coalitions with management and/or shareholders. Based on a sample of 2343 European listed companies between 2012 and 2017, this paper shows that companies with BLER have a higher effective tax rate (ETR) than companies without workers on the board. The analysis suggests that the ability to form coalitions through voting power is a more significant channel for influencing tax behavior than the monitoring mechanism. The policy implications are that governments should consider 'stakeholder governance' such as BLER as one measure supporting their efforts to combat tax avoidance.

Keywords: tax avoidance, worker participation, co-determination, stakeholder governance

JEL Classification: H26, J51

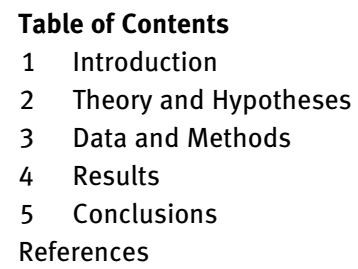

*Corresponding author: Sigurt Vitols, Wissenschaftszentrum Berlin für Sozialforschung, Berlin, Germany; and European Trade Union Institute, Brussels, Belgium, E-mail: vitols@wzb.eu 


\section{Introduction}

Corporate tax avoidance, which is defined as the (legal or illegal) reduction of tax payments by companies (Dyreng, Hanlon, \& Maydew, 2010; Hanlon \& Heitzman, 2010), has become an increasingly prominent public policy issue. First, recent revelations of massive tax evasion by corporations and individuals (Panama Papers, Lux Leaks, Paradise Papers, Swiss Leaks) have received widespread attention by the public. This raises the issue of tax justice, as large corporations and rich individuals are better able to reduce their effective tax rates than smaller enterprises and average wage-earners (Alstadsaeter, Johannesen, \& Zucma, 2019). Second, corporate tax avoidance has a substantial negative impact on the ability of governments to finance public investment and services, particularly in countries hard hit by austerity, and recently, the COVID 19 crisis. Although it is by definition difficult to estimate of the magnitude of tax avoidance and evasion, serious efforts claim that costs are currently at least half a trillion dollars per year. The Tax Justice Network estimates that this accounts for at least $\$ 500$ billion per year, i.e. $20 \%$ of corporate income taxes worldwide The OECD estimates that tax haven 'spillovers' cost the OECD countries over $\$ 400$ billion and non-OECD countries $\$ 200$ billion per year (Crivelli, De Mooij, \& Keen, 2016). One estimate of the amount of 'hidden' wealth (wealth held offshore) is \$21-32 trillion (Henry, 2012).

Many of these mechanisms shift profits within a multinational company from high-tax to low-tax jurisdictions, so that more of the profit is taxed at a lower rate (Biondi, 2017; Quentin, 2017; Beer, De Mooij, \& Liu, 2020). These include transfer pricing (i.e. sale of goods or services at inflated prices from subsidiaries in high tax countries to subsidiaries in low-tax companies), patent boxes (i.e. location of intellectual property in subsidiaries in low-tax countries which charge royalties to subsidiaries in high-tax countries) and high-interest loans made by subsidiaries in low-tax countries to subsidiaries in high-tax countries. While some of these practices are legal, others are clearly illegal, e.g. the outright hiding of wealth and income, for example in complex chains of subsidiaries or in low-transparency jurisdictions. Recent long-term studies document a general decrease in the tax rate that corporations pay (Dyreng, Hanlon, Maydew, \& Thornock, 2017).

Numerous measures to combat tax avoidance have been proposed at national and international levels, such as the G20/OECD initiative on base erosion and profit shifting (Büttner \& Thiemann, 2017; OECD, 2015), the European Commission's proposal for a Common Consolidated Corporate Tax Base (CCCTB), and national and international initiatives for a 'digital services' tax. To date, limited progress has been made in implementing these proposals (Collier, Kari, Ropponen, Simmler, \& Todtenhaupt, 2018). 
Not surprisingly given this growing public interest, research on corporate tax avoidance has greatly expanded in recent years (Avi-Yonah, 2017; Beer et al., 2020). Whereas only a handful of papers on this topic were mentioned in Shackelford and Shevlin's (2001) classic review of tax literature, it has now grown into one of the major subfields of tax research (Hanlon \& Heitzman, 2010). One strand of research focuses on developing definitions and indicators for tax avoidance and estimating its extent. Conceptually, tax avoidance can be seen as a wide variety of actions designed to reduce tax payments. The term 'degree of tax aggressiveness' is often used to characterize the continuum of these actions from legal to illegal, with a large 'grey zone' in between for actions that may conform with the letter but not the spirit of the law, or where the law may be ambiguous. Hanlon and Heitzman (2010) identify 12 commonly used measures of tax avoidance, most of which are variants on the Effective Tax Rate (ETR), which is defined as corporate income tax as a percentage of pretax income. ${ }^{1}$ Variants include cash tax paid versus tax expense and single-year versus multi-year calculations. An indicator of potential tax avoidance is an ETR which is substantially lower than the statutory corporate income tax rate of the company's home country. At the country level, the ETR compares the total corporate income tax paid with aggregate corporate pretax profits. Due to the volatility of annual earnings and tax payments, the ETR is sometimes averaged out over a multiyear period. Research has identified substantial variance at both the company and the country level in the difference between the ETR and the statutory tax rate (Dyreng \& Lindsey, 2009; Markle \& Shackelford, 2012)

A second strand of research analyzes the consequences of tax avoidance. Early work was guided by a model by which a rational actor compares the financial benefits of avoidance with the probability and costs of getting caught (Scholes \& Wolfson, 1992). However, later work looks at the impact of tax avoidance on a firm's reputation and the willingness of consumers to buy its products (Hardeck, Harden, \& Upton, 2019). Engaging in tax shelters can have a negative impact on a company's share price, particularly in sectors close to consumers such as retail (Hanlon \& Slemrod, 2009). Tax avoidance can also have a negative impact on the cost of debt and equity capital and on the firm's value (Bruehne \& Jacob, 2019).

A third strand focuses on the determinants of avoidance (Lietz, 2013). Based on a survey of 137 journal articles on this topic, Bruehne and Jacob (2019) identify 32 such determinants, 15 of which are related to tax avoidance in a consistent manner. One set of determinants are company financial and organizational variables, such as size, profitability, customer base, financial structure (leverage, intangible assets), foreign operations and corporate complexity. A second set of determinants concern the tax

1 The second most popular measure is Book-Tax Differences (BTD), which is the difference between book (accounting) income and taxable income. 
system, such as the statutory tax rate, anti-tax avoidance rules, strictness of enforcement and transparency in tax and financial reporting. A third set of determinants include company behaviors of various types, including political spending and corporate social responsibility (CSR) activities. A fourth set can be considered governance in a broad sense, including ownership structure (family firms, share of institutional investors, share of hedge funds), incentives for company executives and board structure. Kovermann and Velte (2019) analyze 79 journal articles specifically dealing with the relationship between corporate governance and tax avoidance. This research recognizes that a number of actors with different interests are involved in the governance of the corporation, including owners, managers, the tax department and workers. The agency approach, which focuses largely on the relationship between owners and managers, is based on the notion that managers may try to appropriate firm resources for their private benefit rather than to increase shareholder value (Jensen \& Meckling, 1976). Managers may thus have less interest in financial transparency (including tax transparency) and maximizing post-tax profits than owners (Lietz, 2013). Different types of owners may also have different risk orientations and time horizons, for example, hedge funds with a short-term orientation may prioritize short-term after-tax profits and payouts to owners (Cheng, Huang, Li, \& Stanfield, 2012) whereas family owners may prioritize long-run investment and the avoidance of reputational risks (Chen, Huang, Li, \& Shevlin, 2019). Board composition also plays a role, with tax avoidance positively associated with the percentage of men on the board and the presence of directors with tax expertise or an MBA (Kovermann \& Velte, 2019).

However, the bulk of the corporate governance research is based on the agency view, which focuses on owner-manager relationships, and almost none of this research has looked at the potential influence of other 'stakeholders', particularly of workers. Chyz, Leung, Li, and Rui (2013) find that the level of tax avoidance is lower if trade unions are present in the company, and Wilde and Wilson (2018) find that worker whistleblowing also reduces tax avoidance. Kovermann and Velte (2019) specifically call for research on the impact of worker boardroom representation; to date only two working papers have looked at this issue, both finding that worker representation on German supervisory boards reduces tax avoidance (Chyz, Eulerich, Fligge, \& Romney, 2019; Gleason, Kieback, Thomsen, \& Watrin, 2019). ${ }^{2}$

This lack of research on the impact of board level employee representation (BLER) on tax avoidance is particularly surprising given the widespread presence of legal frameworks for BLER in Europe. A majority of the (pre-Brexit) EU-28 countries have legislation mandating or enabling the representation of workers on state owned and/or private sector company boards (Conchon \& Waddington, 2015).

2 Some literature has found a positive relationship between the quality of financial reporting and worker representation through trade unions (Cho, Chung, \& Lee, 2019; Leung, Li, \& Rui, 2009). 
Furthermore, EU legislation supports multinational arrangements for worker participation in specific circumstances, such as mergers between companies based in two or more EU countries (cross-border mergers) (Cremers, Stollt, \& Vitols, 2013; Cremers \& Vitols, 2019). There is a long tradition of research on German codetermination, a particularly well-known system of BLER, which shows that having workers on the board has an impact on company policies and performance (for reviews see Conchon (2011); Jirjahn (2010)). Many of these studies are guided by the 'agency' perspective (Jensen \& Meckling, 1976, 1979) which is for the most part critical about BLER. This perspective, which assumes that economic actors are utility maximizers, expects workers to use any power they have to increase wages and staffing levels above the level that optimizes firm value. Not surprisingly, most of these studies focused on profitability, share price, and productivity. More recent studies, many of which are guided by the 'stakeholder' approach, have a positive view of BLER, as workers are seen as having a longer-term interest in the performance and survival of the firm than institutional investors, many of which are oriented towards quarterly performance (Johnston, 2012; Vitols \& Kluge, 2011). In particular, workers will use their power to protect their investments in firm-specific capital by (in contradiction to the expectations of the agency perspective) accepting lower wages in return for reducing the severity of workforce layoffs during downturns (Kim, Maug, \& Schneider, 2014). Firms with workers on their boards also have a higher rate of longterm investment (Vitols \& Scholz, 2021) and have higher scores on a whole series of sustainability indicators, including not only human resource policies but also environmental performance (Scholz \& Vitols, 2019; Vitols, 2019).

Given that having workers on the board 'matters', BLER could be expected to have an impact on corporate tax behavior. One example of how tax avoidance affects workers is Euro Disney S.C.A., the owning company of Euro Disneyland (now Disneyland Paris) (Saada, 2019). Euro Disney, which was a French company founded in 1985, raised money to build the theme park through an initial public offering on the Paris stock exchange and a subsequent bond issue. Euro Disney had an arrangement with Walt Disney Company, which held 40\% of its shares, whereby Walt Disney received royalties and management fees often exceeding $€ 100$ million per year. As the arrangement was based on revenue rather than profit, and frequently exceeded the level of annual profits, Euro Disney made losses in most years and paid no corporate income taxes, and had to be saved from bankruptcy though a number of re-capitalizations (2005, 2012 and 2014/15). Workers have not benefitted from this tax avoidance practice; on the contrary, the staff has not gained anything from a profit-sharing plan and staffing levels were reduced severely since the 2005 recapitalization, resulting in longer workweeks and higher levels of stress and accidents among the workforce (Lichfield, 2010). If the royalty and management fees had been based on a portion of corporate profit rather than 
sales, it is likely that the French state would have collected more corporate income tax and workers would have been better off. ${ }^{3}$

Revelations of tax avoidance by companies can also have an impact on the workforce through a decline in reputation, stock price crashes and the loss of customers. Examples analyzed in the literature include Dynegy, Tyco, and Xerox (Desai \& Dharmapala, 2006; Kim, Li, \& Zhang, 2011). For example, Dynegy was an energy company based in the US. In 2000/2001 it worked with Arthur Andersen (at that time one of the Big Five accountants) to implement a new type of tax shelter called a commodity basis enhancement strategy. In 2002 this arrangement was revealed in the Wall Street Journal, and the company's stock subsequently lost $97 \%$ of its value. Dynegy almost went bankrupt and was forced to close its energy trading business, resulting in the layoff of $14 \%$ of its workforce.

This article aims at helping plug this research gap by analyzing the relationship between BLER and corporate tax behavior. Based on a sample of 2343 European listed companies, which account for over $95 \%$ of the total capitalization of European stock markets, over the period 2012 to 2017, this paper shows that the presence of workers on the board has a significantly positive effect on a company's ETR. These results suggest that measures that support BLER could be useful instruments for discouraging corporate tax avoidance.

\section{Theory and Hypotheses}

BLER is a widespread feature of corporate governance in Europe. According to the European Trade Union Institute, at the end of 2019, a majority of the (pre-Brexit) EU-28 countries had laws mandating or enabling worker representation in the boards of certain types of companies. ${ }^{4}$ Thirteen countries had provisions for both private sector and state-owned companies: Austria, Czechia, Croatia, Denmark, Finland, France, Germany, Hungary, Luxembourg, the Netherlands, Slovakia, Slovenia and Sweden. Five of these countries had provisions for BLER in stateowned companies: Greece, Ireland, Malta, Poland, and Portugal. Only 10 of the 28 countries had no such arrangement: Belgium, Bulgaria, Cyprus, Estonia, Italy, Latvia, Lithuania, Romania, Spain and the United Kingdom.

Characteristics of BLER systems vary along a number of dimensions (Conchon \& Waddington, 2015). A minimum employment threshold is defined in most countries where the system covers both public and private sector companies. For

3 This case study is based on a presentation by Toufik Saada, Senior Accountant at the French consulting firm Syndex, as well as on press reports.

4 See www.worker-participation.eu. 
example, Sweden and Denmark have quite low thresholds (25 and 35 employees, respectively), whereas representation rights begin at 500 domestic employees in Germany (for one-third representation). Rules regarding the proportion of board members who are worker representatives also vary: one-third is a quite common proportion, but this can go down to one representative (e.g. Croatia) or up to one half of board members (e.g. in German companies with more than 2000 domestic employees). Selection mechanisms also vary; in most countries the workforce elects representatives who may be nominated by trade unions or works councils, but in some cases they are appointed (Austria and Slovenia) or nominated (the Netherlands) by the works council. Common to most systems is the right of worker representatives to full information and voting, on par with the rights of shareholder representatives.

Although only two studies specifically on BLER and tax behavior of companies are known to this author at the time of writing (Chyz et al., 2019; Gleason et al., 2019) there is a rich research tradition on BLER which can be drawn upon for hypothesis development. There are more than 37 quantitative studies on BLER in Germany alone (Scholz \& Vitols, 2019). Many of these studies are guided by the agency approach to the theory of the firm developed by Jensen and Meckling (1976). According to this view, shareholders have a clear interest in maximizing the value of the firm. However, many owners do not manage corporations themselves but rather hire persons to run the company for them. This so-called 'separation of ownership and control' creates an agency problem; managers as rational utilitymaximizers will likely have different interests than the owners, such as the private consumption of firm resources (e.g. purchasing corporate jets) or empire building through mergers and acquisitions, rather than maximizing firm value. The owners of the firm (the 'principals') are thus faced with the twin problems of designing incentives for managers (the 'agents') to maximize firm value and of monitoring managers' behavior, both of which may be costly ('agency costs'). Paying managers with stock options is seen as an efficient incentive, as managers will have a direct interest to increase the value of the firm; monitoring mechanisms include improving financial transparency and appointing persons without ties to management ('independent directors') to the company board. Although costly and imperfect, Jensen and Meckling point out that the modern corporation has survived the market test against alternative forms of organization (1976, p. 357)

Earlier work guided by the agency perspective tended to be critical of BLER, predicting that workers would use any power they have on the board to increase wages and staffing levels, to the detriment of firm value (Gorton \& Schmid, 2004). However, later work using the agency approach has also identified the positive contribution that worker representatives can make to corporate governance. As shown by the examples in the previous section, workers have an interest in 
avoiding the negative employment and reputation impacts that the disclosure of tax avoidance can have, which would align them with shareholders who wish to avoid the risk of stock price crashes (Kim et al., 2011) or with the growing number of sustainability/socially responsible investment funds. Gleason et al. (2019) and Chyz et al. (2019) both point out that worker representatives can improve the monitoring of managers; BLER could thus be in the interests of shareholders insofar as the costs of monitoring are reduced. The latter also point out that workers are generally more risk-averse than mangers, which may possibly align worker representatives more closely with the risk profile of some types of shareholders. Conchon, Gold and Kluge (2010) provide evidence for the 'monitoring' function of BLER, as worker representatives on boards where they account for a small proportion of votes report that the main benefit of BLER is to get information directly from management. On this basis the first hypothesis is formulated:

H1: Tax avoidance is lower in companies with BLER. The relationship between these two variables is non-linear, as the quality of monitoring will not increase proportionately with the increase in the percentage of worker representatives on the board.

A second hypothesis is based on the so-called 'stakeholder' approach to corporate governance, which emphasizes the strength of 'workers' voice' as a determinant of company behavior (Kluge \& Vitols, 2011). According to this view, workers have a longer-term interest in the company than shareholders and management. One indicator of the time horizons of different actors is the average length of attachment to the firm. Whereas the average tenure of workers in Europe is about 10 years (Eurofound, 2015), the average European CEO is in office five years (pwc, 2017) and the average holding period of shareholders less than one year. ${ }^{5}$ The expectation of the stakeholder perspective is that workers will use their influence in corporate governance to resist pressures for short-termism from shareholders and managers and to support policies in the long-run interests of the firm. A large-scale survey of BLERs (Conchon \& Waddington, 2011, 2015) provides support for this alternative hypothesis, as worker representatives on the whole put both 'social' and 'economic' concerns on an equal footing with regard to their activities on the board.

The expectation of stakeholder theory agrees with the agency perspective that workers have an interest in discouraging tax avoidance to avoid the reputational risks of loss of customers and stock price crashes. However, unlike the agency perspective's focus on monitoring, the stakeholder view emphasizes the importance of power relations for workers to influence company policies. With the exception of

5 Data from data.worldbank.org and www.world-exchanges.org. 
worker-owned companies, worker representatives never compose a majority of board members. Their ability to influence company decisions will therefore depend on their ability to enter into coalitions with other actors in corporate governance (shareholders, independent directors, managers). Höpner, (2001) argues that worker representatives can build coalitions with management when shareholders are weak and disorganized. Balsmeier, Bermig, and Dilger (2013) argue that shareholders are often heterogeneous, for example German banks have a different investment and corporate governance orientation than investment funds. Based on a game-theoretic approach to power, they argue that the probability of workers building a coalition with other board members increases more rapidly with an increase in the proportion of workers on the board. Whereas a 'token' worker representative will have practically no chance of entering into a coalition in a large board, the probability of coalition-building will increase disproportionately as the percentage of worker directors. Thus, the second hypothesis is similar to the first hypothesis, the difference being in the shape of the expected relationship between the proportion of worker representatives and the degree of tax avoidance:

H2: The presence of BLER in a company is associated with a lower level of tax avoidance. However, the degree of influence increases disproportionately with the percentage of workers in the board.

In addition to BLER, a number of other variables identified by the literature as important determinants of tax avoidance are included in the analysis (Bruehne \& Jacob, 2019):

- Shareholder structure, as different types of investors may have different attitudes towards tax avoidance and different incentives and capacities to influence management (significantly determined by their share of voting rights)

- Company size, as larger companies may have a greater capacity to avoid taxes, but also may face greater reputational risk due to greater visibility

- Leverage (level of debt), as most countries offer deductions on debt interest payments

- Intangible assets (goodwill, brand, intellectual property rights), which may be easier to channel into tax avoidance schemes than fixed assets

- Capital intensity (property, plant and equipment as a proportion of total assets), which may increase tax payments if accounting depreciation does not match economic depreciation

- Industry affiliation, as firms in different industries have different production techniques and face different types of markets

- Profits, as the level of profitability may affect the company's ability and incentives to avoid taxes and the degree of tax authority scrutiny 
- Statutory tax rate of home country, as higher rates may encourage more tax avoidance

\section{Data and Methods}

Data was gathered from a number of sources to compile the data set needed for analysis. The universe of companies in the analysis was defined by and the data on worker representation obtained from a company data set maintained by the European Federation of Employee Share Ownership (EFES). This data set, which is updated every year, contains information on listed European companies with a market capitalization of at least $€ 200$ million. The number of listed companies included increased in the six years in this study from 2195 in 2012 to 2425 in 2017, yielding a total of 13,868 firm-year observations. For the analysis is important to note that this can effectively be considered to be the full universe of listed European companies (rather than a random sample of companies), as over $95 \%$ of the value of stocks outstanding (market capitalization) is included. Full financial information was available on a total of 10,860 firm-years, resulting in an unbalanced panel with 2343 firms with an average of 4.6 year-observations per firm. Companies from 30 European countries were included in the sample (see Table 1). In line with other studies in this area, financial companies were excluded due to their use of a different system of accounting. Also in line with other studies, only company-years with positive profitability were considered due to the difficulties in interpreting tax expenses as a percentage of negative returns.

The EFES dataset includes information on the total number of board members and the number of worker representatives on company boards. From this data different variables measuring the extent of worker board level representation were calculated. The variable BLER is defined as the percentage of board members with voting rights in a company's highest board (supervisory board in case of a two-tier system, company board in a single-tier system) accounted for by worker representatives. Column 3 of Table 1 (BLER > 0) shows that BLER was present in $22 \%$ of the company-year observations in the data set. A majority of the countries in the study (17 of 30) had at least one company-year with BLER. In only one country (Slovakia) did $100 \%$ of the companies have BLER.

As BLER is a continuous variable, a set of additional variables were created to test for a non-linear relationship between BLER and tax avoidance. BLER1 is a binary variable coded " 1 " if BLER is greater than zero but less than one-third. Overall, $10 \%$ of the company-years fell in this category. BLER2 is a binary variable coded " 1 " if BLER is equal to or greater than one third and less than one half. 
Table 1: Board level employee representation characteristics in sample companies, by country.

\begin{tabular}{|c|c|c|c|c|c|}
\hline \multirow[t]{2}{*}{ Country } & \multirow{2}{*}{$\begin{array}{r}N(\text { firm- } \\
\text { years) }\end{array}$} & \multicolumn{4}{|c|}{ Proportion of companies with: } \\
\hline & & BLER $>0$ & $\begin{array}{r}\text { BLER1 (BLER >0 } \\
\&<0.33)\end{array}$ & $\begin{array}{r}\text { BLER2 (BLER } \geq 0.33 \\
\&<0.5)\end{array}$ & $\begin{array}{r}\text { BLER3 } \\
(B L E R=0.5)\end{array}$ \\
\hline Austria & 197 & 0.75 & 0.11 & 0.63 & 0 \\
\hline Belgium & 280 & 0.03 & 0.03 & 0 & 0 \\
\hline Bulgaria & 13 & 0 & 0 & 0 & 0 \\
\hline Croatia & 63 & 0.54 & 0.54 & 0 & 0 \\
\hline Czechia & 27 & 0.37 & 0 & 0.37 & 0 \\
\hline Denmark & 300 & 0.69 & 0.15 & 0.54 & 0 \\
\hline Estonia & 36 & 0 & 0 & 0 & 0 \\
\hline Finland & 376 & 0.08 & 0.08 & 0 & 0 \\
\hline France & 1309 & 0.29 & 0.27 & 0.02 & 0 \\
\hline Germany & 1099 & 0.66 & 0.01 & 0.18 & 0.46 \\
\hline Greece & 194 & 0.16 & 0.16 & 0 & 0 \\
\hline Hungary & 31 & 0.84 & 0.10 & 0.74 & 0 \\
\hline Iceland & 34 & 0 & 0 & 0 & 0 \\
\hline Ireland & 181 & 0 & 0 & 0 & 0 \\
\hline Italy & 654 & 0 & 0 & 0 & 0 \\
\hline Latvia & 14 & 0 & 0 & 0 & 0 \\
\hline Lithuania & 32 & 0 & 0 & 0 & 0 \\
\hline Luxembourg & 97 & 0 & 0 & 0 & 0 \\
\hline Malta & 34 & 0 & 0 & 0 & 0 \\
\hline Netherlands & 361 & 0.02 & 0.02 & 0 & 0 \\
\hline Norway & 358 & 0.59 & 0.27 & 0.32 & 0.003 \\
\hline Poland & 448 & 0.10 & 0.06 & 0.04 & 0.002 \\
\hline Portugal & 137 & 0 & 0 & 0 & 0 \\
\hline Romania & 47 & 0 & 0 & 0 & 0 \\
\hline Slovakia & 14 & 1.00 & 0 & 1.00 & 0 \\
\hline Slovenia & 65 & 0.94 & 0.03 & 0.91 & 0 \\
\hline Spain & 451 & 0 & 0 & 0 & 0 \\
\hline Sweden & 772 & 0.50 & 0.46 & 0.04 & 0 \\
\hline Switzerland & 751 & 0.02 & 0.02 & 0 & 0 \\
\hline United & 2485 & 0 & 0 & 0 & 0 \\
\hline Kingdom & & & & & \\
\hline Total & 10,860 & 0.22 & 0.10 & 0.07 & 0.05 \\
\hline
\end{tabular}

Source: Own calculations from European Federation of Employee Share Ownership data. BLER is the proportion of supervisory board members (in two-tier companies) or board members (in one-tier companies) accounted for by worker representatives.

Overall, seven percent of the company-years were in this category, which was predominant in Austria, Demark, Hungary, Slovakia and Slovenia. BLER3 is also a binary variable coded "1" if BLER is equal to 0.5. Overall, five percent of the company-year observations fall in this group, almost entirely accounted for by 
Germany (however, Norway and Poland also each have a company in this category).

Financial data and other company information was obtained from S\&P Capital IQ, an online service with information on over 62,000 public and 4.4 million private companies worldwide (see Table 2 for a description of the variables used).

Capital IQ also includes financial variables which the literature identifies might affect tax behavior (see discussion in last section). The dependent variable is ETR, the effective tax rate, defined as annual tax expenses as a percentage of earnings before interest and taxes (EBIT). Due to the presence of extreme outliers, ETR is winsorized at the 0.05 level (i.e. the values of outliers are replaced by the value of cases located at 0.05 and 0.95 levels of the distribution of ETR. This reduces the undue influence outliers can have while at the same time retaining these cases in the data analysis.

Control variables include SIZE, a measure of company size defined as the logarithm of a company's assets in $€$ million, which may have either positive or negative effects on tax avoidance (greater capacity to avoid taxes versus greater visibility and thus risk to reputation). Since tax codes often have a deduction for interest paid on debt, LEVER (debt the percentage of a company's capital

Table 2: Description of variables.

\begin{tabular}{|c|c|}
\hline Variable & Description \\
\hline BLER & $\begin{array}{l}\text { Percent of voting members of highest company board accounted for by worker } \\
\text { representatives }\end{array}$ \\
\hline BLER1 & Binary variable coded " 1 " if BLER $>0 \&<0.33$, "0" otherwise \\
\hline BLER2 & Binary variable coded " 1 " if BLER $\geq 0.33 \&<0.5$, "0" otherwise \\
\hline BLER3 & Binary variable coded " 1 " if BLER $=0.5$, " 0 " otherwise \\
\hline ETR & $\begin{array}{l}\text { Corporate income tax expense divided by earnings before interest and taxes (EBIT), } \\
\text { winsorized at the } 0.05 \text { level }\end{array}$ \\
\hline SIZE & Logarithm of a company's annual assets in $€$ million \\
\hline LEVERAGE & Percentage of a company's assets accounted for by debt \\
\hline R\&D & $\begin{array}{l}\text { Expenditures on research and development as a percentage of assets, winsorized at } \\
\text { the } 0.05 \text { level }\end{array}$ \\
\hline INTANG & Intangible assets as a \% of total company assets \\
\hline CAPINTENS & Net property, plant and equipment as a $\%$ of total assets \\
\hline PROFIT & Return on assets (EBIT/total assets), winsorized at the 0.05 level \\
\hline FREEFLOAT & $\begin{array}{l}\% \text { company's shares held by minority shareholders (those holding less than } 5 \% \text { of } \\
\text { total shares) }\end{array}$ \\
\hline TAXRATE & Nominal corporate tax rate in a company's headquarters country \\
\hline Industry & Series of dummy variables coded according to main SIC 1 digit industry \\
\hline Year & Series of dummy variables for each year in the analysis \\
\hline
\end{tabular}


accounted for by debt) is included, as a higher level of debt may be associated with a lower ETR. Expenditures on research and development as a percent of sales are also included, as many tax codes allow R\&D to be deducted from taxes; this is defined as research and development expenses as a percentage of total assets, winsorized at the 0.05 level to correct for outliers. INTANG is defined as intangible assets as a percentage of total assets; this may be associated with greater tax avoidance since such assets are easier to transfer to low-tax locations. CAPINTENS is net property, plant and equipment (PPE) as a percentage of total assets; this may be associated with higher tax payments, as depreciation allowances for fixed capital may be low. PROFIT is defined as EBIT as a percentage of total assets, winsorized at the 0.05 level. The variable FREEFLOAT (the percentage of shares held by shareholders with less than $5 \%$ of total shares) was also included, as the literature shows that shareholder type may effect corporate tax behavior. Dummy variables for the 1-digit Standard Industrial Classification (SIC) main sector of activity were defined, since industry characteristics can have an influence on tax behavior. Year dummies were also included, since many studies observe a longterm trend towards greater tax avoidance.

A final source of data was the OECD, which maintains a database of corporate tax rates in countries around the world. This database was used to calculate TAXRATE, the nominal rate of taxation in the country in which company has its headquarters. This rate can be expected to be highly correlated with a company's total ETF, as it sets a baseline for taxation of company income in the country where it has its center of operations.

Descriptive statistics are reported in Table 3. The use of winsorization in the ETR, R\&D and PROFIT variables results in a reasonable level of dispersion in the values of these variables. LEVER, INTAN and CAPINTEN all vary between 0 and 1 , as does FREEFLOAT. The lower bound of PROFIT is 0 , as cases with negative profits are excluded from the analysis. Correlation coefficients and their significance levels are reported in Table 4. Although many variables are significantly correlated, the highest coefficient is 0.337 (CAPINTEN and LEVER), indicating that multicollinearity should not be a problem for the analysis.

The method of analysis chosen here is multivariate regression. A panel approach was used to account for company-specific effects, estimated with robust standard errors to control for heteroscedasticity and clustering by headquarters country of company (30 clusters). Random effects models were run, as there are very strong theoretical reasons to prefer this over fixed effects models (Richter \& Schrader, 2017) in this type of estimation. First, the variation over time (within variation) in key explanatory variables is limited, most prominently in the case of BLER, which in many companies has remained at the same level for decades. Second, the companies analyzed in essence comprise the universe of European 
Table 3: Descriptive statistics.

\begin{tabular}{lrrrrrrrr}
\hline Variable & $\boldsymbol{N}$ & Mean & Std. dev. & Min & p25 & Median & p75 & Max \\
\hline BLER & 10860 & 0.067 & 0.142 & 0 & 0 & 0 & 0 & 0.5 \\
ETR & 10860 & 0.189 & 0.151 & -0.238 & 0.123 & 0.203 & 0.272 & 0.501 \\
SIZE & 10860 & 7.226 & 1.799 & 1.777 & 5.901 & 7.013 & 8.319 & 13.712 \\
LEVER & 10860 & 0.228 & 0.179 & 0 & 0.083 & 0.213 & 0.329 & 1 \\
R\&D & 10860 & 0.016 & 0.039 & 0 & 0 & 0 & 0.014 & 0.341 \\
INTANG & 10860 & 0.212 & 0.207 & 0 & 0.035 & 0.149 & 0.339 & 0.895 \\
CAPINTENS & 10860 & 0.252 & 0.236 & 0 & 0.066 & 0.188 & 0.366 & 0.999 \\
PROFIT & 10860 & 0.08 & 0.052 & 0 & 0.042 & 0.069 & 0.109 & 0.199 \\
FREEFLOAT & 10860 & 0.602 & 0.285 & 0 & 0.381 & 0.61 & 0.867 & 1 \\
TAXRATE & 10860 & 25.777 & 6.501 & 9 & 21 & 24.5 & 29.8 & 44.4 \\
\hline
\end{tabular}

non-financial listed companies, rather than being a random sample. Third, the primary interest is in explaining levels of taxation rather than changes in this level.

To test the influence of worker influence overall as well as for nonlinear effects, three different models were run. The first model includes only the full set of control variables. The second model adds the simple continuous variable BLER for worker influence. The third model adds the three binary variables (BLER1, BLER2 and BLER3) to test for non-linear effects of worker board representation on company tax behavior.

\section{Results}

Table 5 presents the results of the three regression models that were run. The results of Model 1 (control variables only) do not deviate from what has been found in previous research. SIZE, the coefficient of which has taken on different signs in different studies, in this case is significantly positively associated with ETR, suggesting that the visibility of larger companies makes it more difficult for them to avoid taxes. The coefficients of both of LEVER and R\&D are negative and highly significant, reflecting the fact that payments of interest on debt and research and development costs are deductible from corporate profit tax in most countries. INTANG is also negative and highly significant, in line with expectations that intangible assets are more easily used in tax avoidance schemes. CAPINTENS has a negative sign but is not significant, suggesting that the capital intensity of companies is not a significant determinant of tax avoidance. The literature has ambiguous expectations regarding profitability, as higher profitability can be seen as an 


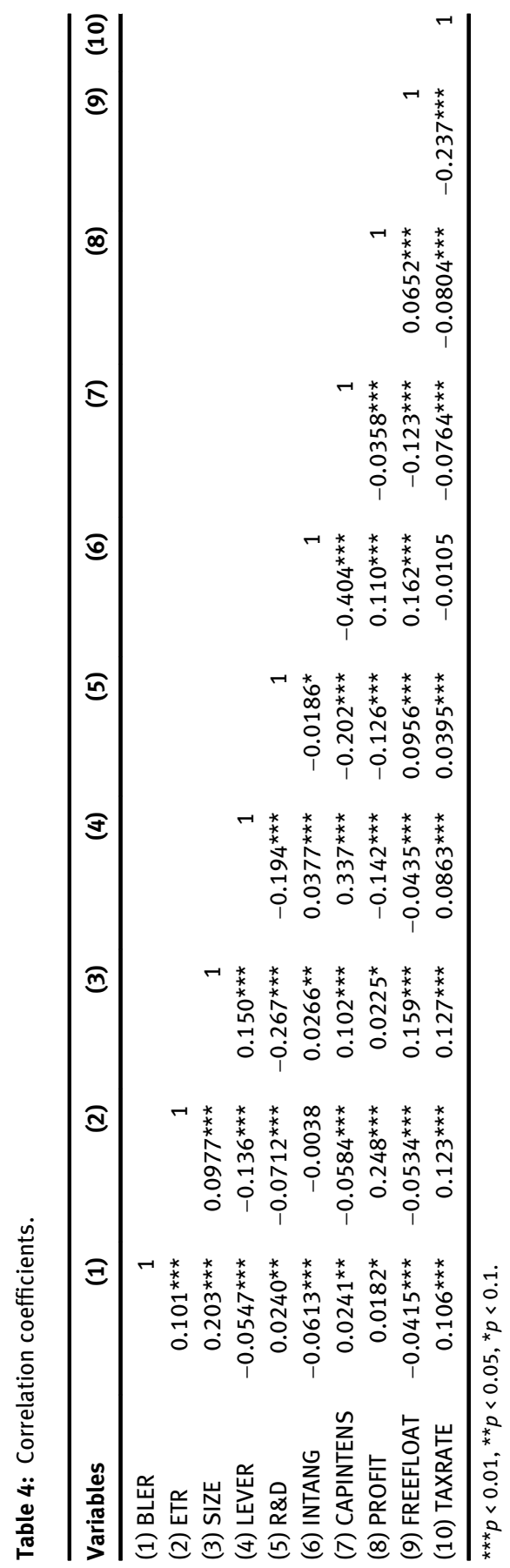


incentive to avoid taxes but also can attract attention from tax authorities. In this case, PROFIT is positive and highly significant, suggesting that the latter mechanism is dominant. FREEFLOAT has a negative sign, in line with the hypothesis that institutional investors will put more pressure on management for (short-term) profits, and thus indirectly for tax avoidance, than other types of investors. However, the coefficient is not significant, thus this effect does not appear to be large, perhaps because institutional investors are not differentiated by type in this analysis. The statutory tax rate TAXRATE is positive and highly significant - not surprising since this rate sets the benchmark against which corporate taxes are paid in the home country of the company. A final result worth noting is that the size and significance of these coefficients are very stable across the three different models tested.

In Model 2 the linear measure of worker board level representation BLER augments the basic model with all the control variables (Model 1). The coefficient of BLER is positive and highly significant, indicating that the presence of worker representatives on company boards is associated with less tax avoidance. Furthermore, it suggests that tax avoidance may decrease with an increasing proportion of worker representatives on the board. Given that the coefficient of BLER is 0.0670, the expected ETR for a firm with the highest level of BLER (0.5) would be 0.0335 (about one third of a percentage point) higher than the expected ETR for a firm without BLER, all other things being equal.

To explore the shape of the relationship between BLER and tax avoidance more closely, Model 3 uses the three dummy variables BLER1, BLER2 and BLER3, which measure different proportions of BLER. The coefficients of all three are positive, and the size increases from BLER1 to BLER2 to BLER3; however, the coefficient for BLER1 is not significant, suggesting that a proportion of worker representatives of less than one third has a weak at best impact on tax avoidance. Interestingly, the coefficient for BLER3 is 0.0313, which is roughly the same estimate that Model 2 generated for companies with one-half worker representation.

The fact that BLER1 is not significant is taken as evidence supporting the rejection of $\mathrm{H} 1$, i.e. the hypothesis that the main effect of worker representatives on tax avoidance is through improved monitoring of management. Unlike worker voting power, which increases substantially as the proportion of worker representatives of the board increases, monitoring can in principle be done by a small number of worker representatives (Conchon et al., 2010). Therefore, the ability to monitor would not be expected to improve significantly with an increase in worker representation beyond this minimum level, and the expectation is that BLER1 would be positive and significant. However, the fact that only BLER2 and BLER3 are positive and significant is taken as evidence supporting $\mathrm{H} 2$, which is that the probability of workers being able to form coalitions with (some) shareholders and/ or managers should increase disproportionately with the increase in the 
Table 5: Effective tax rate determinants.

\begin{tabular}{|c|c|c|c|}
\hline VARIABLES & Model 1 & Model 2 & Model 3 \\
\hline BLER & & $\begin{array}{l}0.0670^{\star \star \star} \\
(0.0214)\end{array}$ & \\
\hline BLER1 & & & $\begin{array}{l}0.000389 \\
(0.00813)\end{array}$ \\
\hline BLER2 & & & $\begin{array}{l}0.0247^{\star *} \\
(0.0103)\end{array}$ \\
\hline BLER3 & & & $\begin{array}{l}0.0313^{\star \star \star} \\
(0.0101)\end{array}$ \\
\hline SIZE & $\begin{array}{l}0.00558^{\star \star \star} \\
(0.00155)\end{array}$ & $\begin{array}{l}0.00439 * * \\
(0.00193)\end{array}$ & $\begin{array}{l}0.00463^{\star *} \\
(0.00191)\end{array}$ \\
\hline LEVER & $\begin{array}{l}-0.123^{\star \star \star} \\
(0.0124)\end{array}$ & $\begin{array}{l}-0.120^{\star \star \star} \\
(0.0132)\end{array}$ & $\begin{array}{l}-0.120^{\star \star \star} \\
(0.0132)\end{array}$ \\
\hline RND & $\begin{array}{l}-0.324^{\star \star \star} \\
(0.0913)\end{array}$ & $\begin{array}{l}-0.350^{\star \star \star} \\
(0.0850)\end{array}$ & $\begin{array}{l}-0.348^{\star \star \star} \\
(0.0850)\end{array}$ \\
\hline INTANG & $\begin{array}{l}-0.0667^{\star \star \star \star} \\
(0.0165)\end{array}$ & $\begin{array}{l}-0.0636^{\star \star \star} \\
(0.0156)\end{array}$ & $\begin{array}{l}-0.0631^{\star * \star} \\
(0.0157)\end{array}$ \\
\hline CAPINTENS & $\begin{array}{l}-0.0339 \\
(0.0211)\end{array}$ & $\begin{array}{l}-0.0343 \\
(0.0213)\end{array}$ & $\begin{array}{l}-0.0342 \\
(0.0210)\end{array}$ \\
\hline PROFIT & $\begin{array}{l}0.285^{\star \star \star} \\
(0.0997)\end{array}$ & $\begin{array}{l}0.287^{\star \star \star} \\
(0.100)\end{array}$ & $\begin{array}{l}0.290^{\star \star \star} \\
(0.0992)\end{array}$ \\
\hline FREEFLOAT & $\begin{array}{l}-0.0120 \\
(0.00869)\end{array}$ & $\begin{array}{l}-0.0105 \\
(0.00861)\end{array}$ & $\begin{array}{l}-0.0104 \\
(0.00851)\end{array}$ \\
\hline TAXRATE & $\begin{array}{l}0.00370^{\star \star \star} \\
(0.00125)\end{array}$ & $\begin{array}{l}0.00363^{\star \star \star} \\
(0.00113)\end{array}$ & $\begin{array}{l}0.00367^{\star * \star} \\
(0.00113)\end{array}$ \\
\hline Constant & $\begin{array}{l}0.0718 \\
(0.0504)\end{array}$ & $\begin{array}{l}0.0760 \\
(0.0482)\end{array}$ & $\begin{array}{l}0.0738 \\
(0.0477)\end{array}$ \\
\hline Observations & 10,860 & 10,860 & 10,860 \\
\hline Number of firms & 2343 & 2343 & 2343 \\
\hline Industry dummies & YES & YES & YES \\
\hline Year dummies & YES & YES & YES \\
\hline Wald chi2 & 5441 & 10925 & 11633 \\
\hline Prob. > chi2 & 0.00 & 0.00 & 0.00 \\
\hline Overall R-sq. & 0.0952 & 0.0990 & 0.0984 \\
\hline
\end{tabular}

Random effects panel regression with standard errors clustered by headquarters country. Fixed effects for industry and year. Dependent variable is the effective tax rate (ETR) defined as tax expense divided by earnings before interest and taxes (EBIT) winsorized at the 0.05 level. Robust standard errors in parentheses $\left({ }^{\star \star *} p<0.01\right.$, $\left.{ }^{\star *} p<0.05,{ }^{\star} p<0.1\right)$. 
percentage of these workers on the board. While this does not rule out that tax avoidance decreases due to improved monitoring of management through BLER, it does appear that worker power and the ability of worker representatives to enter into coalitions with shareholders and/or managers is the dominant mechanism in this context. ${ }^{6}$

\section{Conclusions}

Based on an analysis of 2343 European listed companies, which represent over 95\% of European stock market capitalization, between 2012 and 2017, this paper helps fill a gap in the literature on corporate tax avoidance by analyzing the relationship between board level employee representation (BLER) and companylevel effective tax rates (ETR). In their review of 79 articles on corporate governance and tax avoidance, Kovermann and Velte (2019) note the striking lack of research on this relationship, on which research has only recently started (Chyz et al., 2019; Gleason et al., 2019); this despite the fact that BLER is a widespread feature of corporate governance in Europe. The results of this analysis build on previous research suggesting that BLER 'matters' in corporate governance and extends this analysis to the tax behavior of companies.

A second contribution is that this is one of the few papers with a research design explicitly comparing two different theories (agency theory and coalition theory) and their explanations of how worker representatives can influence corporate performance. The bulk of studies on BLER are dominated by one or the other perspective. Both perspectives agree that workers and their representatives in the board have an interest in curbing aggressive tax avoidance to preventing taxrelated company scandals which might be damaging to their company's reputation and long-term prospects. However, they hypothesize different mechanisms for how BLER affects tax behavior (monitoring versus voting power coalitions). The analysis in this paper suggests that worker power and coalition theory is better at explaining this relationship that agency theory.

The implication of this analysis for public policy is that BLER should be considered for addition to the arsenal of mechanisms that could potentially discourage tax avoidance behavior. A number of EU Directives define procedures

6 As a robustness check, the regressions were run again excluding German companies, since BLER3 (one half representation of workers on boards) is almost entirely found only in Germany. With the exception of BLER3, the results were in line with the three models run above; BLER was positive and significant in Model 2, and BLER1 was positive but not significant and BLER2 was positive and significant in Model 3. 
for the negotiation of BLER in specific circumstances, such as the formation of companies with European legal forms (the European Company and European Cooperative) or cross-border reorganizations (cross-border mergers, divisions and conversions), and the European trade union movement has demanded the extension of BLER to a wider variety of situations (Picard, 2019). Furthermore, proposals have recently been made to introduce BLER into countries without a tradition of co-determination (e.g. in the US, UK and Israel). Understanding the tax implications of BLER can help inform these policy debates. One fruitful avenue for further research would be case studies of how worker representatives form positions on company tax policy and utilize their power on the board to engage with shareholder representatives and management on these issues. Another line of research could be to include variables differentiated by type of investor (e.g. hedge fund, bank, sovereign wealth fund, etc.) and by type of (non-worker) board member (e.g. independent representative, executive director, etc.).

Acknowledgments: The author would like to thank participants in a session at the SASE 2019 Conference in New York organized by the SASE Network on Accounting, Economics, and Law and four anonymous reviewers for useful comments on an earlier version of this paper. Vera Fabinyi provided valuable research assistance.

\section{References}

Alstadsaeter, A., Johannesen, N., \& Zucma, G. (2019). Tax evasion and inequality. The American Economic Review, 109(6), 2073-2103.

Avi-Yonah, R. (2017). International tax avoidance - Introduction. Accounting, Economics, and Law: A Convivium, 7(1). https://doi.org/10.1515/ael-2016-0071.

Balsmeier, B., Bermig, A., \& Dilger, A. (2013). Corporate governance and employee power in the boardroom: An applied game theoretic analysis. Journal of Economic Behavior \& Organization, 91, 51-74.

Beer, S., De Mooij, R., \& Liu, L. (2020). International corporate tax avoidance: A review of the channels, magnitudes, and blind spots. Journal of Economic Surveys, 34(3), 660-688.

Biondi, Y. (2017). The firm as an enterprise entity and the tax avoidance conundrum: Perspectives from accounting theory and policy. Accounting, Economics, and Law: A Convivium, 7(1). https://doi.org/10.1515/ael-2017-0001.

Bruehne, A., \& Jacob, M. (2019). Corporate tax avoidance and the real effects of taxation: A review. Retrieved from https://ssrn.com/abstract=3495496.

Büttner, T., \& Thiemann, M. (2017). Breaking regime stability? The politicization of expertise in the $\mathrm{OECD} / \mathrm{G} 20$ process on BEPS and the potential transformation of international taxation. Accounting, Economics, and Law: A Convivium, 7(1). https://doi.org/10.1515/ael-2016-0069.

Cheng, C. S. A., Huang, H. H., Li, Y., \& Stanfield, J. (2012). The effect of hedge fund activism on corporate tax avoidance. The Accounting Review, 87(5), 1493-1526. 
Chen, S., Huang, Y., Li, N., \& Shevlin, T. (2019). How does quasi-indexer ownership affect corporate tax planning? Journal of Accounting and Economics, 67(2), 278-296.

Cho, E. J., Chung, J. R., \& Lee, H.-Y. (2019). The role of labor unions in corporate transparency: Focusing on the role of governance in auditor change process. Sustainability, 11(9), 2643.

Chyz, J. A., Eulerich, M., Fligge, B., \& Romney, M. A. (2019). Codetermination and aggressive reporting: Audit committee employee representation, tax aggressiveness, and earnings management. Retrieved from https://ssrn.com/abstract=3441342.

Chyz, J. A., Leung, W. S. C., Li, O. Z., \& Rui, O. (2013). Labor unions and tax aggressiveness. Journal of Financial Economics, 108(3), 675-698.

Collier, R., Kari, S., Ropponen, O., Simmler, M., \& Todtenhaupt, M. (2018). Dissecting the EU's recent anti-tax avoidance measures: Merits and problems. Munich, Germany: ifo Institute. Econpol Policy Report. Retrieved from Munich: https://www.ifo.de/DocDL/EconPol_Policy_ Report_08_2018.pdf.

Conchon, A. (2011). Board level employee representation rights in Europe: Facts and trends. Brussels: ETUI. (121). Retrieved from Brussels https://www.etui.org/sites/default/files/R\% 20121\%20Conchon\%20BLER\%20in\%20Europe\%20EN\%20WEB.pdf.

Conchon, A., \& Waddington, J. (2011). Board level employee representation in Europe: Challenging common place prejudices. In N. Kluge \& S. Vitols (Eds.), The sustainable company: A new approach to corporate governance. Vol. 1. (1st ed.) (pp. 91-111). Brussels: ETUI.

Conchon, A., \& Waddington, J. (2015). Board-level employee representation in Europe: Priorities, power and articulation. New York,NY: Routledge.

Conchon, A., Gold, M., \& Kluge, N. (2010). 'In the union and on the board': Experiences of boardlevel employee representatives across Europe. Brussels: ETUI.

Cremers, J., \& Vitols, S. (2019). Exercising voice across borders: Workers' rights under the EU cross-border mergers directive. Brussels: ETUI.

Cremers, J., Stollt, M., \& Vitols, S. (2013). A decade of experience with the European company. Brussels: ETUI. https://doi.org/10.1002/9781118567371.

Crivelli, E., De Mooij, R., \& Keen, M. (2016). Base erosion, profit shifting and developing countries. FinanzArchiv: Public Finance Analysis, 72(3), 268-301.

Desai, M. A., \& Dharmapala, D. (2006). Corporate tax avoidance and high-powered incentives. Journal of Financial Economics, 79(1), 145-179.

Dyreng, S. D., \& Lindsey, B. P. (2009). Using financial accounting data to examine the effect of foreign operations located in tax havens and other countries on U.S. multinational firms' tax rates. Journal of Accounting Research, 47(5), 1283-1316.

Dyreng, S. D., Hanlon, M., \& Maydew, E. L. (2010). The effects of executives on corporate tax avoidance. The Accounting Review, 85(4), 1163-1189.

Dyreng, S. D., Hanlon, M., Maydew, E. L., \& Thornock, J. R. (2017). Changes in corporate effective tax rates over the past 25 years. Journal of Financial Economics, 124(3), 441-463.

Eurofound (2015). Job tenure in turbulent times. Luxembourg: Publications Office of the European Union. Retrieved from https://www.eurofound.europa.eu/sites/default/files/ef publication/field_ef_document/ef1524ennew.pdf.

Gleason, C. A., Kieback, S., Thomsen, M., \& Watrin, C. (2019). Monitoring or payroll maximization? What happens when workers enter the boardroom? Retrieved from https://ssrn.com/ abstract $=3322700$.

Gorton, G., \& Schmid, F. A. (2004). Capital, labor, and the firm: A study of German codetermination. Journal of the European Economic Association, 2(5), 863-905. 
Hanlon, M., \& Heitzman, S. (2010). A review of tax research. Journal of Accounting and Economics, 50(2-3), 127-178.

Hanlon, M., \& Slemrod, J. (2009). What does tax agressiveness signal? Evidence from stock price reactions to news about tax shelter involvement. Journal of Public Economics, 93(1-2), 126-141.

Hardeck, I., Harden, J. W., \& Upton, D. R. (2019). Consumer reactions to tax avoidance: Evidence from the United States and Germany. Journal of Business Ethics, 170, 75-96.

Henry, J. S. (2012). The price of offshore revisited: New estimates for 'missing' global private wealth, income, inequality, and lost taxes. Retrieved from https://www.taxjustice.net/wpcontent/uploads/2014/04/Price_of_Offshore_Revisited_120722.pdf.

Höpner, M. (2001). Corporate governance in transition: Ten empirical findings on shareholder value and industrial relations in Germany. Cologne: Max-Planck-Institute for the Study of Societies. Working Paper 05/2001. Retrieved from https://ssrn.com/abstract=287460.

Jensen, M. C., \& Meckling, W. H. (1976). Theory of the firm: Managerial behavior, agency costs and ownership structure. Journal of Financial Economics, 3(4), 305-360.

Jensen, M. C., \& Meckling, W. H. (1979). Rights and production functions: An application to labormanaged firms and codetermination. Journal of Business, 52(4), 469-506.

Jirjahn, U. (2010). Ökonomische Wirkungen der Mitbestimmung in Deutschland: Ein update. Düsseldorf. [Working Paper 186]. Retrieved from https://www.boeckler.de/pdf/p_arbp_186. pdf.

Johnston, A. (2012). Recent developments in stakeholder theory: From the productive coalition to the governance of social cost. In S. Vitols \& J. Heuschmid (Eds.), European company law and the sustainable company - $A$ stakeholder approach. Brussels: ETUI/GOODCORP.

Kim, J. B., Li, Y., \& Zhang, L. (2011). Corporate tax avoidance and stock price cash risk: Firm-level analysis. Journal of Financial Economics, 100(3), 639-662.

Kim, E. H., Maug, E. G., \& Schneider, C. (2014).Labor representation in governance as an insurance mechanism [ECGI working paper series in finance 411/2014]. Retrieved from https://www. erim.eur.nl/fileadmin/erim_content/documents/ceconf/Maug_LabRep_ECGI_2014-02-23f. PDF.

Kovermann, J., \& Velte, P. (2019). The impact of corporate governance on corporate tax avoidanceA literature review. Journal of International Accounting, Auditing and Taxation, 36(C). https:// doi.org/10.1016/j.intaccaudtax.2019.100270.

Leung, W. S. C., Li, O. Z., \& Rui, O. M. (2009). Labour union and accounting conservatism. Rochester, NY: SSRN. [AAA 2010 Financial Accounting and Reporting Section (FARS) Paper]. Retrieved from https://ssrn.com/abstract=1462594.

Lichfield, J. (2010). The dark side of Disneyland Paris. Independent. London: The Independent. Retrieved from https://www.independent.co.uk/news/world/europe/the-dark-side-ofdisneyland-paris-1964505.html.

Lietz, G. M. (2013). Determinants and consequences of corporate tax avoidance. Retrieved from https://ssrn.com/abstract=2363868.

Markle, K. S., \& Shackelford, D. A. (2012). Cross-country comparisons of corporate income taxes. National Tax Journal, 65(3), 493-527.

OECD (2015). 2015 Final reports. OECD/G20 base erosion and profit shifting project. Paris: OECD Publishing. Retrieved from https://www.oecd.org/ctp/beps-2015-final-reports.htm.

Picard, S. (2019). ETUC recommendations regarding the Cross-border Mergers Directive: Get real, get employees involved and be consistent. In J. Cremers \& S. Vitols (Eds.), Exercising voice 
across borders: workers' rights under the EU Cross-border Mergers Directive (pp. 77-84). Brussels: ETUI.

pwc. (2017). 2016 CEO success study. New York, NY: PricewaterhouseCoopers.

Quentin, D. (2017). Corporate tax reform and "value creation": Towards unfettered diagonal Reallocation across the global inequality chain. Accounting, Economics, and Law: A Convivium, 7(1). https://doi.org/10.1515/ael-2016-0020.

Richter, A., \& Schrader, S. (2017). Levels of employee share ownership and the performance of listed companies in Europe. British Journal of Industrial Relations, 55(2), 396-420.

Saada, T. (2019). EuroDisney: Tax optimisation and its social consequences. [Powerpoint Presentation]. Brussels.

Scholes, M. S., \& Wolfson, M. A. (1992). Taxes and business strategy: A planning approach. Englewood Cliffs, N.J.: Prentice Hall. https://doi.org/10.3386/w4171.

Scholz, R., \& Vitols, S. (2019). Board-level codetermination: A driving force for corporate social responsibility in German companies? European Journal of Industrial Relations, 25(3), 233-246.

Shackelford, D., \& Shevlin, T. (2001). Empirical tax research in accounting. Journal of Accounting and Economics, 31(3), 321-387.

Vitols, S. (2019). What drives sustainability in companies? Examining the influence of board level employee representation on responsible practices in large European companies. Berlin, Germany: WZB. Paper presented at the ILERA, Düsseldorf.

Vitols, S., \& Kluge, N. (Eds.) (2011). The sustainable company: A new approach to corporate governance (1st ed.). Brussels: ETUI.

Vitols, S., \& Scholz, R. (2021). Unternehmensmitbestimmung und langfristige Investitionen in deutschen Unternehmen. WSI-Mitteilungen, 74(2), S. 87-97.

Wilde, J. H., \& Wilson, R. J. (2018). Perspectives on corporate tax planning: Observations from the past decade. Journal of American Taxation Association, 40(2), 63-81. 